\title{
Impact of Climate Resilient Practices under NICRA Project in Ri Bhoi District of Meghalaya
}

\author{
S. Medhi*, M. Islam, U. Barua, M. Sarma, M.G. Das, E.C. Syiemlieh, \\ P. Bordoloi and B. Mukhim
}

Krishi Vigyan Kendra, Ri Bhoi, ICAR RC for NEH Region, Umiam-793103, Meghalaya, India

*Correspondence author: samirmedhi1993@gmail.com

\begin{abstract}
The present study was conducted to identify the technological and socio-economic impact of the climate resilient technologies demonstrated at National Innovation for Climate Resilient Agriculture (NICRA) Kyrdem village at Ri Bhoi district of Meghalaya. To assess the impact, the ex-post-facto research design, where before and after comparisons on different aspects of NICRA project were done. The statistical tools like chi square and Cramer's V were applied for analysis of the collected information for jalkund and vermicompost to draw the meaningful and logical conclusions. Findings reveal that the average cultivable land area and productive parameters for crops and livestocks of NICRA farmers after the project interventions was significantly higher than that of before the implementation of the interventions all through in kharif and rabi seasons. Findings of cropping intensity, annual savings, expenditure pattern and crop yield were significantly higher in comparison to before implementation of the intervention. Findings of the study exhibited an encouraging impact of the demonstrated technologies in various spheres of farmer's life of NICRA village.
\end{abstract}

Keywords: Crop yield, annual savings, production parameter, NICRA village

Climate is changing gradually, at its own pace, since the evolution of earth but presently, it has gained momentum due to unintended manmade disturbances. These changes are having adverse impact on human health and the overall environment on which we depend. As agricultural production is one of the sectors of society most vulnerable to climate variability and change it is important to explore linkages between agricultural ecosystems, uncertain trajectories of future climate, and land use changes over periods of time (Parry and Carter 1989, Meinke et al. 2006). The hill agriculture system heavily depends on nature and natural resources like water, soil and forest and more vulnerable by the occurrence of extreme weather events such as rainfall, drought, floods, cold waves and relative humidity (Malla, 2014). Rainfall changes have been distributed unevenly through the seasonal cycle: increases concentration in late spring to summer, whereas, winter has seen little or no change. Furthermore, the increase has been particularly marked near the western margin of the Pampas, displacing westward the transition to semiarid regions that represent the boundary of rainfed agriculture (Berbery et al. 2006). High variation in environmental factors such as temperature, rainfall and others affect crop growth negatively and certain crops get positively affected due to change in these environmental factors. Thus, change in climatic variables may have positive and negative impact on agricultural productivity and food security situation in the economy (Greg et al. 2011). Changes in rainfall due to global climate change may affect the surface moisture availability, which becomes important for germination and crop stand establishment in the rainfed areas. According to study, India is facing its worst water crisis in history and 21 major cities will run out of groundwater by 2020, in less than 2 years, affecting 100 million people, Groundwater accounts for $40 \%$ of India's water supply. Modifications in the surface and groundwater availabilities with the rainfall change are difficult to be observed 
when the land use and land cover are so rapidly changing (Khan et al. 2009). Further, socioeconomic aspects can be dealt in two ways, one working out the cost-benefit analysis for various climate change scenarios by using econometric-process models and the other, generating the socio-economic scenario of future which links with the cropping system model for further impact analysis (Antle and Capalbo 2001). As a response to these challenges, both farmers as well as research community developed an extensive range of agricultural practices which could augment farming systems' resiliency to climate change (Wezel et al. 2014). Research on the impact of climate change and vulnerability on agriculture is a high priority in India as the impact, if it follows the predictions, is expected to be widespread and severe. Developing the ability to confidently estimate the impacts of climate change on agriculture is critically important (Khan et al. 2009). Looking into the concerns, Indian Council of Agricultural Research initiated the National Innovation for Climate Resilient Agriculture (NICRA) across the country in collaboration with ICAR research institutes, SAUs and KVKs. The project is implemented in 100 districts involving over one lakh farm families across the country. This project was also implemented in Krishi Vigyan Kendra) Ri Bhoi, ICAR RC for NEH Region, Umiam and the project site village Kyrdem in the year 2011. Various modules implemented under Technology Demonstration Component (TDC) viz. natural resource management, crop management, livestock and fisheries and institutional interventions which deal with adaptation of crop and livestock production systems to climate variability. Since its beginning, NICRA project demonstrated and supported to adopt a wide-ranging technologies and improved practices for mitigating climate change to provoke farming as business especially in hills. This study was undertaken to study the impact of different spheres of project interventions including technological and socio economic impacts.

\section{MATERIALS AND METHODS}

To describe the impact of interventions performed under NICRA, the adopted village, Kyrdem of Ri Bhoi district of Meghalaya was selected. The expost-facto research design was used. In this regard, before and after comparisons on various variables were obtained with the help of baseline data and recall memories of respondents. The research locale was selected purposely, as the project has been implemented in this village since its inception in the year 2011. The Kyrdem village of Ri Bhoi district represent rainfed agro ecosystem and mostly affected by terminal drought, frost, cold wave, hail storm and high intensity \& erratic rainfall. The study locale was vulnerable to climatic variability. Data was collected by utilizing observation tools and secondary sources of data. The secondary data were used along with the primary data to supplement and triangulation of the study through NICRA annual reports, KVK data and block level data. The data collection was done on the interventions implemented by the KVK, under NICRA. Impact of the interventions was studied and values of before and after the interventions were compared and tested with suitable test statistics appropriate for the intervention.

\section{RESULTS AND DISCUSSION}

\section{Water harvesting structures -jalkund for vegetable cultivation}

KVK, Ri Bhoi initiated a programme to construct some small water harvesting structures called 'Jalkund' under the NICRA project in some of the farmers field of Kyrdem village. This would enable the farmers to utilize the water during the lean season. The changing weather, unpredictable rainfall pattern and drought are the main factors contributing to water stress. Therefore, proper water conservation and efficient utilization of rain water is needed in the area. Before NICRA there were no jalkund unit in Kyrdem village which deprived them from cultivating vegetable during lean season giving a negative growth rate in cultivated area and net income. The technology was conducted in the field of 12 farmers at NICRA adopted Kyrdem village to provide water for cultivation during lean season. Twelve Jalkund (5x4x2 Cu.m) of capacity 40,000 litres has been demonstrated with 0.34 ha/ Jalkund for vegetable cultivation (Cabbage: $\mathrm{H}-$ 139, Cauliflower: White Contessa Tomato: Megha Tomato 3, Broccoli: Green Magic, Coriander etc making 4.08 ha under vegetable cultivation and an increase in the cropping intensity to $204 \%$.

From the table 1 it is seen that, Yield and Net return 
are significantly associated with Area at 0.011 and 0.001 level of probability. This indicates that higher the level of these significant variables of the respondents higher would be their yield and net return. Further with the Cramer's V value of 0.779 and 0.845 , it could be commented that yield and net return orientation had strong association with area and would have more influence on that parameter. Increased annual savings through climate resilient interventions were also quoted in previous studies (Schrooten and Stephan 2003, Jasna et al. 2017). The increased net return is an outcome of addition in area of cultivation and inclusion of jalkund unit and climate resilient crop varieties provided by KVK Ri Bhoi.

Table 1: Chi-square test of Area under vegetable cultivation with Yield of vegetable \& Net return

\begin{tabular}{cccccc}
\hline $\begin{array}{c}\text { Sl. } \\
\text { No. }\end{array}$ & Parameter & Parameter & $\begin{array}{c}\text { Chi- } \\
\text { Square } \\
\text { value }\end{array}$ & $\begin{array}{c}\text { 'p' } \\
\text { value }\end{array}$ & $\begin{array}{c}\text { Cramer's } \\
\text { 'V' }\end{array}$ \\
\hline 1 & Yield & \multirow{2}{*}{ Area } & $14.571^{* *}$ & 0.011 & 0.779 \\
2 & Net return & & $17.143^{* *}$ & 0.001 & 0.845 \\
\hline
\end{tabular}

*Significant at 0.05 level of probability **Significant at 0.01 level of probability.

Production of organic manure through vermicompost [weed biomass $(40 \%)+$ agricultural waste $(60 \%)]$ : Vermicomposting is a process of artificial rearing of earthworms and the process of using them for converting the degradable biomass into a simpler waste soluble substance rich in nutrients, beneficial soil micro flora and has the properties of inhabiting pathogenic microbes. Total 12 vermicompost unit has been demonstrated covering 12 ha of area in paddy and vegetable cultivation in 47 farmers field with average net return of ₹ 16,940/unit/year with $\mathrm{B}: \mathrm{C}$ ratio of 2.25. It has also added in improvement of soil health and enrichment of soil nutrients (VC:N-1.9\%, $\mathrm{P}_{2} \mathrm{O}_{5}-4.48 \%, \mathrm{~K}_{2} \mathrm{O}-0.85 \%$ ) making it cost effective method and farmers friendly intervention. There were no vermicompost unit in Kyrdem village before the intervention by KVK, Ri Bhoi.

\section{Performance parameters/indicators}

\begin{tabular}{cccc}
\hline $\begin{array}{c}\text { Production/ } \\
\text { harvest (q) }\end{array}$ & $\begin{array}{c}\text { No. of } \\
\text { harvest/yr }\end{array}$ & $\begin{array}{c}\text { Total } \\
\text { harvest(q/yr/ } \\
\text { unit) }\end{array}$ & $\begin{array}{c}\text { Earthworm } \\
\text { production } \\
\text { (no.) }\end{array}$ \\
\hline 10.6 & 3 & 30.6 & 5250 \\
\hline
\end{tabular}

From the table 2 it is seen that, area and Net return are significantly associated with yield at 0.001 and 0.001 level of probability. This indicates that higher the level of these significant variables of the respondents higher would be their yield and net return. Further with the Cramer's V value of 0.907 and 0.921 , it could be commented that area and net return orientation had strong association with yield and would have more influence on that parameter. Hence, organic compost production has direct impact on climate resiliency by reducing greenhouse gas emissions and also providing sustainable livelihood and income generation under aberrant climate condition.

Table 2: Chi-square test of Yield of compost with Income of vegetable \& Net return

\begin{tabular}{cccccc}
\hline $\begin{array}{c}\text { S1. } \\
\text { No. }\end{array}$ & Parameter & Parameter & $\begin{array}{c}\text { Chi- } \\
\text { Square } \\
\text { value }\end{array}$ & $\begin{array}{c}\text { 'p' } \\
\text { value }\end{array}$ & $\begin{array}{c}\text { Cramer's } \\
\text { 'V' }\end{array}$ \\
\hline 1 & Area & Yield & $77.263^{* *}$ & 0.001 & 0.907 \\
2 & Net return & & $119.71^{* *}$ & 0.001 & 0.921 \\
\hline
\end{tabular}

*Significant at 0.05 level of probability **Significant at 0.01 level of probability.

Mulching in ginger \& turmeric on raised bunds across the slope: Mulching of beds with green leaves or any other mulching material is an important and essential operation in ginger and turmeric cultivation. The effect of mulching on growth and yield of ginger \& turmeric has already been established from various studies. Mulching is essential for weed control, for moisture conservation and to protect the beds from the beating action of rain. Heavy mulch can change the physical and chemical environment of the soil underneath, resulting in the increased availability of $\mathrm{P}$ and $\mathrm{K}$. Mulching increased the germination and growth of plants in terms of height and number of tillers. Weed growth in the control plots was much higher than the plots mulched. Total 1 ha area of each crop demonstrated in 40 farmer's field with an area expansion of 10 ha in ginger and 7 ha in turmeric. There was a change in income by 2.56 fold in ginger and 2.67 folds in turmeric in addition to that there was a reduction in weed growth by $30-35 \%$, soil erosion mitigation by $60-65 \%$ and improve soil condition, crop yield and availability of soil moisture. 
Table 3: Before-After comparison of yield of ginger \& turmeric

\begin{tabular}{ccc}
\hline Crop yield & $\begin{array}{c}\text { Before } \\
\text { intervention } \\
(\mathbf{q} / \mathbf{h a})\end{array}$ & $\begin{array}{c}\text { After } \\
\text { intervention } \\
(\mathbf{q} / \mathbf{h a})\end{array}$ \\
\hline Ginger (Var. Nadia) & 85 & 250 \\
Turmeric (Var. MT1) & 225 & 310 \\
\hline
\end{tabular}

Table 4: Before-After comparison of income

\begin{tabular}{ccccc}
\hline \multirow{2}{*}{ Crops } & \multicolumn{4}{c}{ Changes in income $(₹ /$ ha/yr) } \\
\cline { 2 - 5 } & $\begin{array}{c}\text { Before } \\
\text { intervention }\end{array}$ & $\begin{array}{c}\text { After } \\
\text { intervention }\end{array}$ & $\begin{array}{c}\text { Before } \\
\text { BCR }\end{array}$ & $\begin{array}{c}\text { After } \\
\text { BCR }\end{array}$ \\
\hline Ginger & 52,000 & $1,32,800$ & 1.70 & 2.70 \\
Turmeric & 56,200 & $1,50,000$ & 1.74 & 2.81 \\
\hline
\end{tabular}

SRI paddy- zero till pea cropping system: Rice (Oryza sativa L.) is the principal food crop of the NER of India and cultivated in about 3.5 million hectares area with average productivity of $1.78 \mathrm{t}$ ha $^{-1}$ which is far below than the country's average productivity of $2.4 \mathrm{t} \mathrm{ha}^{-1}$ (Das et al. 2014).

Table 5: Before-After comparison of yield of Paddy and ginger along with system productivity

\begin{tabular}{ccc}
\hline Crop yield & $\begin{array}{c}\text { Before } \\
\text { intervention } \\
\text { (q/ha) }\end{array}$ & $\begin{array}{c}\text { After } \\
\text { intervention } \\
\text { (q/ha) }\end{array}$ \\
\hline $\begin{array}{c}\text { SRI Paddy (var. } \\
\text { Shahsarang) }\end{array}$ & 22.9 & 39.52 \\
$\begin{array}{c}\text { Zero till pea (var } \\
\text { prakash) } \\
\text { System } \\
\text { productivity }\end{array}$ & 0 & 21.76 \\
\hline
\end{tabular}

Table 6: Before-After comparison of income

\begin{tabular}{|c|c|c|c|c|}
\hline \multirow[b]{2}{*}{ Crops } & \multicolumn{4}{|c|}{ Changes in income (₹/ha/yr) } \\
\hline & $\begin{array}{c}\text { Before } \\
\text { intervention }\end{array}$ & $\begin{array}{c}\text { After } \\
\text { intervention }\end{array}$ & $\begin{array}{c}\text { Before } \\
\text { BCR }\end{array}$ & $\begin{array}{l}\text { After } \\
\text { BCR }\end{array}$ \\
\hline $\begin{array}{l}\text { SRI Paddy (var. } \\
\text { Shahsarang) }\end{array}$ & 13810 & 33428 & 1.75 & 2.16 \\
\hline $\begin{array}{l}\text { Zero till pea } \\
\text { (var prakash) }\end{array}$ & NIL & 32500 & NIL & 2.48 \\
\hline $\begin{array}{l}\text { SRI paddy-Zero } \\
\text { till pea system }\end{array}$ & 13810 & 68328 & 1.75 & 2.65 \\
\hline
\end{tabular}

With the adoption of appropriate crop production technology such as SRI (Das et al. 2012; Uphoff et al. 2013) and aerobic production technology (Patel et al. 2010) etc., it is possible to reduce the yield loss due to climatic aberrations to a great extent and ensure better livelihood (Das et al. 2014). The SRI technique requires less amount of seeds $\left(5-7 \mathrm{~kg} \mathrm{ha}^{-1}\right)$ and water, ensures early maturity and sustains soil health. Zero tillage technology in which skill based knowledge on the technology was imparted to the farmers for augmenting the production and productivity of second crop after rice under soil-moisture stress condition by reduction in tillage, retention of adequate amount of crop residues for moisture conservation and soil organic matter maintenance thereby enhancing the cropping intensity that lead to increase in income and ameliorate the socioeconomic status of the farmers of Kyrdem village. KVK Ri Bhoi demonstrated 4.5 ha of each crop in 39 farmers field. There was an increase in yield by $72.57 \%$ in SRI, system productivity by $98.33 \%$ and cropping intensity from $113 \%$ to $203 \%$. Seed cost reduced by $75-85 \%$ and advancement of harvesting by 10-12 days.

Low cost polyhouse technology for multiple cropping: Production of offseason vegetable nurseries under protected structure has become a profitable business. The main purpose of raising nursery plants in protected structure is to get higher profit and disease free seedlings in off season to raise early crop in protected condition or/and open field condition. The low cost polyhouse is economical for small and marginal farmers, who cannot afford huge cost of high-tech poly house. The temperature inside the poly house is $6-10{ }^{\circ} \mathrm{C}$ higher than outsides during winter. The cold waves during winter season (December to February) do not enter inside the poly house and inside environment becomes conducive for quick germination of seed and growth of seedlings. Many times farmers produce good amount of cucumber, capsicum and tomatoes during main season, which eventually leads to the market glut and fall in price. On the other hand, due to weather extremes during winter, it is difficult to grow high value vegetables like tomato, capsicum, cucumber, lettuce etc. in open condition. Therefore, low-cost polyhouse technology was introduced in NICRA village by KVK Ri Bhoi for off-season production of vegetable nurseries as well as for raising crops of high value vegetables. A total of 12 polyhouses was demonstrated for multiple cropping. There was a substantial increase in yield from $185 \mathrm{q} /$ ha to $232 \mathrm{q} /$ ha with an average net return of ₹ 39,226/unit/yr including nursery with 
Table 7: Comparison of hanging rope method with rack method:

\begin{tabular}{|c|c|c|c|c|c|}
\hline Technology Detail & No. of farmers & Yield (kg/unit) & Parameters Assessed & Net income (₹/ha) & $\mathrm{B}: \mathrm{C}$ ratio \\
\hline $\begin{array}{l}\text { Oyster mushroom } \\
\text { cultivation under hanging } \\
\text { rope (P. florida \& P. sajor caju) }\end{array}$ & 40 & 115 & $\begin{array}{l}\text { Weight of mushroom: } 65 \mathrm{~g} \\
\text { Length: } 14 \mathrm{~cm} \\
\text { Breadth: } 10 \mathrm{~cm}\end{array}$ & 14,500 & 2.9 \\
\hline $\begin{array}{l}\text { Oyster mushroom } \\
\text { cultivation on bamboo rack } \\
\text { (P. florida \& P. sajor caju) }\end{array}$ & 16 & $72 \mathrm{~kg}$ & $\begin{array}{l}\text { Weight of mushroom: } 45 \mathrm{~g} \\
\text { Length: } 9 \mathrm{~cm} \\
\text { Breadth: } 6 \mathrm{~cm}\end{array}$ & 9,500 & 1.78 \\
\hline
\end{tabular}

B:C ratio of 2.3. The technology was horizontally spread to 3 SHGs of 45 members of 12 household.

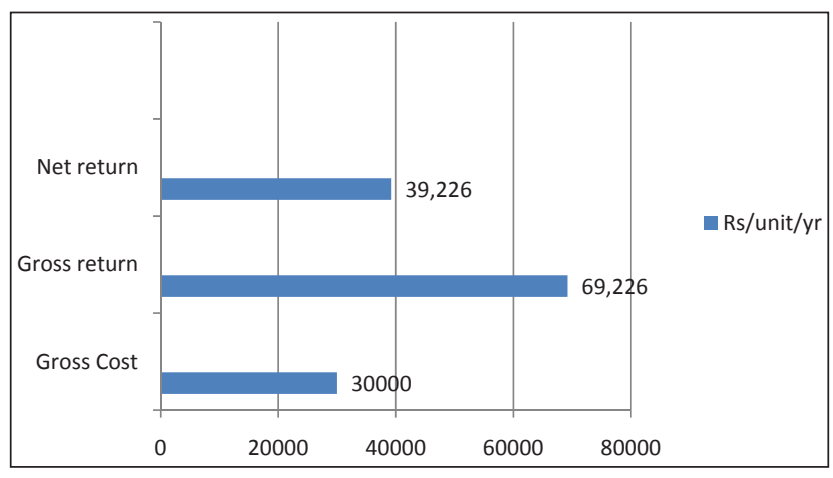

Fig. 1: Income generated from cultivating vegetable under low cost polyhouse

Hanging rope practice of oyster mushroom cultivation for women empowerment: Hanging rope practise of mushroom cultivation with three to four beds per rope was found out to be very effective with more yield where the entire bag can be utilized where earlier in rack system the bottom part of the mushroom bag could not be utilized resulting in less output of the economic part, also the cost is reduced since less bamboos are required making the practise very compatible among the marginal farmer with high relative advantage. Four numbers of demonstrations was given under mushroom cultivation covering 40 numbers of farm women under 4 SHGs. Average yields of mushroom ranges from $98-105 \mathrm{~kg} / \mathrm{unit} / 100$ bed with total yield of $200 \mathrm{~kg}$ of fresh mushroom per year/unit. Profitability enhanced by 2.9 folds with gross cost of ₹ 7000/unit/year and gross return of ₹ 16,000 / unit/year along with providing employment to 40 farm women for additional income generation for improving their socio-economic profile.

Cultivation of short duration variety to mitigate terminal drought: Short duration, drought tolerant crop varieties were demonstrated for delayed sowing and deficit rainfall conditions to improve the resilience of farming in the drought prone areas. Farmers adopted short duration varieties when faced with delayed onset of monsoon. Fifteen numbers of farmers were selected for demonstration covering 1 ha of area with paddy var. vivek dhan 82. After cultivating the short duration variety an increase in yield was recorded from 20.5 q/ha to 31.5 $\mathrm{q} /$ ha over the year (53.66\% increases in production) enhancing the profitability by 2.05 folds. Paddy var. vivek dhan is also resistant to blast and tolerant under low temperature condition and compensates sowing date of second crop by 7-10 days.

Table 8: Before-After comparison of income:

\begin{tabular}{|c|c|c|c|c|}
\hline \multirow[b]{2}{*}{ Crops } & \multicolumn{4}{|c|}{ Changes in income (₹/ha/yr) } \\
\hline & $\begin{array}{c}\text { Before } \\
\text { intervention }\end{array}$ & $\begin{array}{c}\text { After } \\
\text { intervention }\end{array}$ & $\begin{array}{c}\text { Before } \\
\text { BCR }\end{array}$ & $\begin{array}{l}\text { After } \\
\text { BCR }\end{array}$ \\
\hline $\begin{array}{c}\text { Paddy } \\
\text { (var vivek } \\
\text { dhan } 82 \text { ) }\end{array}$ & 13810 & 23805 & 1.5 & 2.05 \\
\hline
\end{tabular}

Nutrition garden for health improvement of farm families: Vegetables help combat malnutrition and diversify diets. Dietary diversification balances the diet by enhancing supply of essential micro-nutrients leading to improved health, enhanced thinking ability and increased efficiency. Kitchen gardening involves many crops that can be repeatedly harvested to meet a family's vegetable needs throughout the year. The crops and their varieties are scientifically selected to be highly nutritious with few pest and disease problems. Though vegetables are recognized as the most important source of these micronutrients, yet the per capita vegetable consumption in India ( $86 \mathrm{~g} /$ day) is far below the FAO's recommended (200 g/day). The limited supply of vegetables, especially during the offseason, higher market price and lower appreciation or awareness regarding their consumption are key 
factors that limit the vegetable consumption rate in the developing world. Therefore, KVK Ri Bhoi through NICRA took the initiative to improve the poor nutritional status of farm families by introducing nutritional kitchen garden for overall diet improvement. Vegetable nutrition garden can be established on a small piece of land provides healthy and pesticide free vegetables for the family. A total of 13 household were covered under nutrition garden covering 2.8ha of area. An annual return of ₹ 5040/household/year with profitability of 2.02 benefited the marginal farmers by reducing their input cost on vegetables and also improving their purchasing capacity of meat and fish. Thus, fresh and safe to eat vegetables will be available for domestic consumption all the year round and improved consumption of vegetables will help to address nutrient deficiency disorders like anemia, goiter, night blindness and so on.

Paddy-pea cropping system under raised bed: Raised bed planting system promotes crop intensification and diversification besides saving irrigation water. In raised bed system, saves 30-40\% water as compared to conventional flood irrigation practice (RWC, 2002, Mann and Meisner, 2003). Benefits of Raised bed system also include (i) fewer weeds, (ii) facilitates seeding into relatively dry soils (iii) vigorous and better crop stands, (iv) savings of costly seed (v) reduced crop-lodging and seed and fertilizer contact (vi) better drainage, improved rainwater conservation; and crop productivity and(vii) minimizes wilt infestation and avoids temporary water logging problems. When these crops are planted on the raised beds they escape crop losses due to temporary water logging.

Table 9: Before-After comparison of yield of Paddy and ginger along with system productivity

\begin{tabular}{ccc}
\hline Crop yield & $\begin{array}{c}\text { Before } \\
\text { intervention } \\
\text { (q/ha) }\end{array}$ & $\begin{array}{c}\text { After } \\
\text { intervention } \\
\text { (q/ha) }\end{array}$ \\
\hline Paddy (var. RCM 10) & 20.3 & 40.52 \\
Pea (Vikash) & 0 & 13.33 \\
System productivity & 20.3 & 67.18 \\
\hline
\end{tabular}

Thus, the raised bed planting system also offers significant opportunities for intensification and diversification along with utilization of paddy field after harvesting to regenerate soil nutrients through leguminous pea plant. Forty two farmers were imparted demonstration by KVK Ri Bhoi on paddy-pea cropping system covering 5.5ha of area. A substantial increase in yield was recorded by $73.5 \%$, system productivity by $98.47 \%$ and cropping intensity from $110 \%$ to $207 \%$.

Table 10: Before-After comparison of income

\begin{tabular}{ccccc}
\hline \multirow{2}{*}{ Crops } & \multicolumn{4}{c}{ Changes in income (₹/ha/yr) } \\
\cline { 2 - 5 } & $\begin{array}{c}\text { Before } \\
\text { intervention intervention }\end{array}$ & $\begin{array}{c}\text { After } \\
\text { Before } \\
\text { BCR }\end{array}$ & $\begin{array}{c}\text { After } \\
\text { BCR }\end{array}$ \\
\hline $\begin{array}{c}\text { Paddy (var. } \\
\text { RCM 10) }\end{array}$ & 14830 & 35823 & 1.85 & 2.36 \\
$\begin{array}{c}\text { Pea (Vikash) } \\
\text { Paddy-Pea } \\
\begin{array}{c}\text { cropping } \\
\text { system }\end{array}\end{array}$ & NIL & 33470 & NIL & 2.58 \\
\hline
\end{tabular}

Maize-blackgram cropping system: KVK Ri Bhoi introduced composite variety RCM 1-3 which takes around 110-115 days to mature from seed to seed. This duration is utilized for second and third crop in rotation. Similarly, during the winter season farmers are unable to grow any crop due available soil moisture stress as no and/ or very scanty rainfall is received during the period (October to February). Hence, for growing rabi season crops especially for blackgram at least 30 per cent maize stover and weed biomass is used as mulch for reducing the evaporation from soil surface and maintaining the soil temperature and also acts as a measures for reducing soil erosion due to monocropping. The cropping system also provides security to farmers in case of crop failure due to high intensity unseasonal rain and hailstorm. Training was provided to 15 farmers along with demonstration in 1ha of land under maize-balckgram cropping system. An average MEY was recorded to be 59.23q/ ha with average additional net return of ₹ 47,722 (Profitablity ratio 2.37). After following the maizebalckgram cropping system cropping intensity changed from $113 \%$ to $200 \%$. An improvement in soil health was also recorded as per the table below:

\begin{tabular}{cc}
\hline Before & After \\
\hline pH: 4.89 & pH: 5.13 \\
EC: 0.06 & EC: 0.07 \\
OC: 0.61 & OC: 0.64 \\
N: 298.8 & N: 301.8 \\
P: 75.3 & P: 76.3
\end{tabular}




$\begin{array}{cc}\text { K:123.8 } & \text { K:123.8 } \\ \text { S:3.85 } & \text { S:3.89 } \\ \text { Zn: } 2.0 & \text { Zn: } 2.22 \\ \text { B: } 0.14 & \text { B: } 0.16 \\ \text { Fe: } 30.2 & \text { Fe: } 32.6\end{array}$

Deep litter housing of pigs: Deep litter is an animal housing system, based on the repeated spreading of straw or sawdust material in indoor booths. An initial layer of litter is spread for the animals to use for bedding material and to defecate in, and as the litter is soiled, new layers of litter are continuously added by the farmer. Deep litter may be considered as a natural means to disposing of animal faeces. "The deep litter cultivation is a modern ecological breeding technique based on decomposing faeces by microbiological methods, a post processing method for pig manure." Hence, KVK Ri Bhoi popularized the idea among the NICRA farmers by demonstrating 6 units with 3 piglets of Hampshire cross per unit and floor space of $3 \mathrm{sqm} / \mathrm{pig}$. After adopting the technique the growth rate of pig was increased by $33.64 \%$ and mortality was reduced by $6.5 \%$.

\section{Changes in body growth rate \& mortality}

\begin{tabular}{cc}
\hline Before intervention & After intervention \\
\hline Body weight gain $110 \mathrm{~g} /$ day/ & Body weight gain $147 \mathrm{~g} /$ day/ \\
pig \\
Mortality- $12.5 \%$
\end{tabular}

\section{Changes in income}

\begin{tabular}{lcc}
\hline \multicolumn{2}{c}{ Change in income (₹/Yr.) } & $\begin{array}{c}\text { \% change in } \\
\text { income }\end{array}$ \\
\hline Before & After & $125 \%$ \\
\hline 13200 & 29700 & \\
\hline
\end{tabular}

Duck cum fish integrated farming system: Water surface of ponds can be put into full utilization by duck raising. Fish ponds provide an excellent environment to ducks which prevent them from infection of parasites. Ducks feed on predators and help the fingerlings to grow. Duck raising in fish ponds reduces the demand for protein to $2-3$ $\%$ in duck feeds. Duck droppings go directly into water providing essential nutrients to increase the biomass of natural food organisms. The daily waste of duck feed (about 20 - 30 gm/duck) serves as fish feed in ponds or as manure, resulting in higher fish yield. Ducks also serve as bio aerators as they swim, play and chase in the pond. This disturbance to the surface of the pond facilitates aeration. The feed efficiency and body weight of ducks increase and the spilt feeds could be utilised by fish. Ducks keep aquatic plants in check. Duck increase the pond productivity through dabbling by $35-40 \%$ with the increase of phytoplankton population as feed for fish. No additional land is required for duckery activities. It results in high production of fish, duck eggs and duck meat in unit time and water area. It ensures high profit through less investment. KVK Ri Bhoi demonstrated 1 IFS unit combining 36 numbers of farmers under 1 SHG. Khaki Campbell cross breed was used with duck stocking of 200 ducklings/ha and fish stocking of 6000 fingerlings/ ha. A change in income by 2.5 folds with $\mathrm{B}: \mathrm{C}$ ratio of 2.83 comparatively improved the economic condition of farmers through this initiative by KVK Ri Bhoi under NICRA project.

\section{Changes in parameters}

\begin{tabular}{cc}
\hline Before Intervention & After Intervention \\
\hline $\begin{array}{c}\text { Fish Production: } 71 \mathrm{~kg} / 0.1 \\
\text { ha }\end{array}$ & Egg production: $10 \mathrm{nos} . / \mathrm{bird} /$ \\
month \\
$\begin{array}{c}\text { (without integration of } \\
\text { duck) }\end{array}$ & Fish Production: $92 \mathrm{~kg} / 0.1 \mathrm{ha}$ \\
\hline
\end{tabular}

\section{Changes in income}

\begin{tabular}{lcc}
\hline \multicolumn{2}{c}{ Change in income (₹/Yr.) } & $\begin{array}{c}\text { \% change in } \\
\text { income }\end{array}$ \\
\hline Before & After & $150 \%$ \\
\hline 12780 & 31960 & \\
\hline
\end{tabular}

Improved low cost elevated housing system for goat farming: Goat shed or housing plays important role in any successful goat farming. Goat farming in North East region is becoming very popular as more farmers are showing interest due to increased demand of goat meat in domestic and export materials. Another primary reason is that goat farming can bring profits in short time. For proper housing the farmers were instructed to construct a low cost elevated goat shed with locally available materials like bamboo, thatch grass. The size of the house was as per the recommended space requirement of 15-20 sq. feet of floor space per adult goat. KVK Ri Bhoi demonstrated 36 units of Assam hill goat breed (2 goats/unit) increasing 
the functional knowledge of farmers. The goats suffered less stress during winter as the temperature is maintained and also increased their body growth rate by $26.67 \%$ and reduction in mortality rate by $6 \%$.

\section{Changes in body growth rate and mortality}

\begin{tabular}{cc}
\hline Before Intervention & After Intervention \\
\hline $\begin{array}{c}\text { Body weight gain- } 45 \mathrm{~g} / \text { day/ } \\
\text { goat }\end{array}$ & Body weight gain- $57 \mathrm{~g} /$ day/ \\
Mortality- $11 \%$ & goat \\
\hline
\end{tabular}

\section{Changes in income}

\begin{tabular}{ccc}
\hline Change in income (₹/Yr.) & $\begin{array}{c}\text { \% change in } \\
\text { income }\end{array}$ \\
\hline Before & After & 176 \\
\hline 1700 & 4700 & \\
\hline
\end{tabular}

Backyard poultry farming through vanaraja birds: Backyard poultry is a part of farming systems mainly run by women farmers' women in rural areas. The major challenge with local birds is low egg production and weight gain. Vanaraja is a dual purpose chicken variety. Vanaraja is suitable for rural communities where it can be reared in backyard feeding mainly from natural scavenged food with minimal supplementation. It grows faster and produces more eggs than the available desi variety of poultry. The additional income with less care has given economical support to farmers with change in income by 3.6 folds with $\mathrm{B}: \mathrm{C}$ ratio of 2.69. Birds can be reared with less investment and less technicality. Vanaraja reared for both meat and egg purpose. Within six months it gives eggs. One bird will be 2 to $2.5 \mathrm{~kg}$ in a year. Farmer can get both egg and meat. It was observed that the birds are more sensitive to cold temperatures. The sheds were constructed and chicks were released with lighting facilities for reducing their mortality rate. Demonstration was conducted for 135 beneficiaries with twenty numbers of birds/unit.

\section{Enhancement of growth parameters}

\begin{tabular}{cc}
\hline Traditional poultry rearing & Backyard poultry rearing \\
\hline Body weight gain: $105 \mathrm{~g} /$ & Body weight gain: $610 \mathrm{~g} /$ \\
bird/month & bird/month \\
Egg production: 6 nos./bird & Egg production: 11 nos./bird \\
/month & /month \\
Mortality: $18 \%$ & Mortality: $8 \%$ \\
\hline
\end{tabular}

\section{Changes in income}

\begin{tabular}{ccc}
\hline Change in income (₹/Yr.) & $\begin{array}{c}\text { \% change in } \\
\text { income }\end{array}$ \\
\hline Before & After & $264 \%$ \\
\hline 1590 & 5790 & \\
\hline
\end{tabular}

Pig-cum-fish integrated farming system: The objective of livestock cum fish integrated farming system is to produce a optimum level of phytoplankton, zooplankton and bacteria which are protein rich natural feed for fish by livestock excreta. Some carnivorous fish eat pig dung directly and digestibility of pig dung is very high. One pig voids about $500 \mathrm{~kg}$ of dung in a year. There is no additional land requirement for pig farm. Pond water is utilized for bathing of pigs. Requirement of supplementary feed for fish reduces considerably in pig cum fish farm. KVK Ri Bhoi demonstrated 2 IFS unit with pig breed Hampshire cross. Fingerlings of catla, rohu and mrigal was provided with stocking density of 8000 fingerlings per ha. Yearly fish yield was found out to be $108 \mathrm{~kg} / 0.1$ ha after integration of pig along with 8 piglets for starting another unit of IFS helping the poor and marginal farmer to earn extra revenue with good dividend. Farmers were able to earn an average annual return of ₹ $34,570 /$ unit/yr with B:C ratio of 2.05 .

\section{Enhancement of growth parameters}

\begin{tabular}{cc}
\hline Before intervention & After intervention \\
\hline $\begin{array}{c}\text { Fish Production: } 65 \mathrm{~kg} / 0.1 \\
\text { ha/yr }\end{array}$ & Body weight gain :148g/pig/ \\
day \\
(without integration of pig) & Fish production: 108 \\
& $\mathrm{~kg} / 0.1 \mathrm{ha} / \mathrm{yr}$ \\
\hline
\end{tabular}

Breed up gradation of pig and goat through AI \& natural breeding with improved male germplasm: Artificial insemination (AI) in swine is not a new technique. Perhaps the greatest advantage of AI is that it permits us to make greater use of new, superior genetics at a potentially lower cost than some natural-service systems and with less risk of disease transmission. Purchasing semen allows genetic diversity, which can be used to optimize crossbreeding systems on smaller farms, and increased genetic progress. This can be achieved without the expense of purchasing and maintaining a single, superior boar. In order to improve the productive performance of local pig and goat and 
also to improve their knowledge on improved breeding practices KVK Ri Bhoi demonstrated AI in twelve households with 12 animals (6 goats and 6 pigs). Farmer has enhanced their profitability by $24 \%$ in pigs and $30 \%$ in goats.

\section{Enhancement of growth parameters}

\begin{tabular}{cc}
\hline Before intervention & After intervention \\
\hline Body weight gain of pig: & Body weight gain of pig: \\
110g/pig/day & $150 \mathrm{~g} / \mathrm{pig} / \mathrm{day}$ \\
Litter size at birth: 6 nos & Litter size at birth: 9 nos. \\
Body weight gain of goat: & Body weight gain of goat: \\
$44 \mathrm{~g} /$ goat/day & $57 \mathrm{~g} / \mathrm{goat} / \mathrm{day}$ \\
Twinning: $65 \%$ & Twinning $: 60 \%$ \\
\hline
\end{tabular}

\section{Changes in income}

\begin{tabular}{ccccc}
\hline \multicolumn{2}{c}{$\begin{array}{c}\text { Before up gradation } \\
\text { (₹/unit) }\end{array}$} & \multicolumn{2}{c}{$\begin{array}{c}\text { After up gradation } \\
\text { (₹/unit) }\end{array}$} \\
\hline Animal & Net return & B:C & Net return & B:C \\
\hline Pig & 9064 & 1.37 & 19970 & 1.70 \\
Goat & 3990 & 1.33 & 8670 & 1.73 \\
\hline
\end{tabular}

Composite fish culture for higher income: Fish is the cheapest and most easily digestible animal protein and was obtained from natural sources from time immemorial for consumption by human beings.

However, due to over exploitation, climate change and pollution, the availability of fish in natural waters has declined considerably forcing fishery experts to adopt various methods to increase its production. Fish farming in controlled or under artificial conditions has become the easier way of increasing the fish production and its availability for consumption. Farmers can easily take up fish culture in village ponds, tanks or any new water body and can improve their financial position substantially. It also creates gainful employment for skilled and unskilled youths. The technology developed for fish culture in which more than one type of compatible fishes is cultured simultaneous is the most advanced and popular in the country. This technology is known as Composite Fish Culture. This technology enables to get maximum fish production from a pond or a tank through utilization of available fish food organisms in all the natural niches, supplemented by artificial feeding. Any perennial fresh water pond/tank retaining water depth of 2 metres can be used for fish culture purpose. However, the minimum level should not fall below one metre. Even seasonal ponds can also be utilised for short duration fish culture. KVK Ri Bhoi demonstrated Composite Fish Culture technology in eight farmers pond ( 0.43 ha each) after renovation with fingerlings comprising Grass Carp (25\%), Common Carp (40\%), Big Head Carp (25\%) and Amur carp (10\%). After following the technology the fish production for farmer increased from $45 \mathrm{~kg} /$ pond to $110 \mathrm{~kg} /$ pond accelerating the income of farmer from ₹ 7650/pond/year to ₹ 9860/ pond/year. In addition to the exotic carps, Amur carp (modified variety of common carp) which are considered to have more growth and climate resistant variety compare to normal common carp.

Sweet potato based pig feeding system: Householdbased pig production in Ri Bhoi generally relies on local crop resources to feed the animals. Feeding is one of the main production constraints for smallholder pig farmers due to the seasonality, high cost and poor quality of feeds; coupled with limited knowledge of supplementation strategies. As a coping strategy, farmers extensively use crop residues, grasses, weeds and kitchen leftovers to feed their animals. Sweet potato vines are the most commonly used fodder but they are highly seasonal and perishable. Simple silage making for feed conservation combined with strategic supplementation is an easy and affordable option for pig feeding during periods of feed scarcity and will contribute to reduce wastage of sweet potato residues. KVK Ri bhoi scientifically planned an intervention for sweet potato based pig feeding system and demonstrated in four farmers' field (0.1 ha each) with 3 piglets/unit. Farmer were trained to prepare a mixture of sweet potato and vine (DM 30\%)/0.1 ha.

\begin{tabular}{lc}
\hline $\begin{array}{l}\text { Cost of production of } 1 \mathrm{~kg} \text { DM of sweet } \\
\text { potato }\end{array}$ & $₹ 12$ \\
Cost of $1 \mathrm{~kg}$ computed pig feed & $₹ 25$ \\
Farmer saved pig feed cost & By $52 \%$ \\
Body weight gain & By $36.46 \%$ \\
Income enhanced & By ₹ $1710 /$ pig \\
\hline
\end{tabular}

\section{Changes in parameters}

\begin{tabular}{cc}
\hline \multicolumn{2}{c}{ Body weight gain } \\
\hline With sweet potato & Without sweet potato \\
\hline $32 \mathrm{~kg} /$ pig at 6 months & $23.45 \mathrm{~kg} / \mathrm{pig}$ \\
\hline
\end{tabular}




\section{Zero energy cool chamber for enhancing the shelf life of perishable fruits \& vegetable}

Horticulture produces plays a significant part in increasing the total agricultural product of the country. The post-harvest loss of developed countries is $5-20 \%$ and developing country is about $20-50 \%$. The magnitude of these losses in developing countries like India is comparatively higher due to a variety of reasons; mainly due to lack of infrastructure like cold storage, warehouses, refrigerated vans, etc., needed for the post-harvest management of the perishables and poor utilization of the fruits and vegetables. Cooling chambers works on the principle of evaporative cooling. Evaporative cooling is the reduction in temperature resulting from the evaporation of a liquid, which removes latent heat from the surface from which evaporation takes place. This structure is erupted over a single row of brick floor and double layer of brick wall in sides with an inter space of $7.5 \mathrm{~cm}$ filled with river sand. These chambers helps to maintain a very high humidity of $95 \%$ throughout the year and it also reduce the temperature of the chamber even during summer months. These chambers are ideal for storage for a short period and helpful for small and marginal farmers to store their produce. Based on this technical knowledge KVK Ri Bhoi demonstrated 4 unit of ZECC for 4 SHGs consisting of $40 \mathrm{farm}$ women. The intervention helped in increasing the shelf life of perishable fruits and vegetables maintaining the quality of the produce from harvesting to marketing. The production parameter for shelf life of fruits and vegetable are mentioned below:

\begin{tabular}{cc}
\hline Harvested produce & Shelf-life \\
\hline Leafy vegetable & 10-12 days (IC), 1 day (OC) \\
Other vegetable & 8-10 days (IC), 2-4 days (OC) \\
Tomato & 8 days (IC), 2 days (OC) \\
Mushroom & 10 days (IC), 2 days (OC) \\
Betel leaves & 25 days (IC), 7 days (OC) \\
\hline
\end{tabular}

*IC-Inside condition, OC-Outside condition.

\section{Value addition of pork, mushroom \& ginger for skill development of farm families}

A broad definition of value added is to economically add value to a product by changing its current place, time and from one set of characteristics to other characteristics that are more preferred in the marketplace. As a specific example, a more narrow definition would be to economically add value to a product (such as pork meat) by processing it into a product (such as pork pickle) desired by customers giving them a boost in family income. Underutilized local fruits like Sohphie can also be utilized for preparation of Sohphie pickle by the SHG farmers which are having high elasticity of demand in the local market. KVK Ri Bhoi conducted training on value addition of pork, mushroom \& ginger for skill development and capacity building of farm women. Two SHGs unit have been formed comprising of 40 numbers of marginal farm women. The intervention has developed an entrepreneurship attitude among the members and thus helps them in increasing their income. Before the intervention most of the products which are highly perishable are sold at very cheap prices which did not contribute much in improving their economic status.

\section{Quantity of products produced per year}

\begin{tabular}{cc}
\hline Products produced & Quantity \\
\hline Ginger ale & 100 bottles \\
Pork pickle & 100 packets \\
Sohphie pickle & 60 bottles \\
Ginger wine & 50 bottles \\
Mushroom pickle (Dehydrated) & 100 packets \\
Mulberry wine & 30 bottles \\
Tomato pickle & 50 bottles \\
Tapioca \& Potato chips & 50 packets \\
\hline
\end{tabular}

\section{Income generated per year}

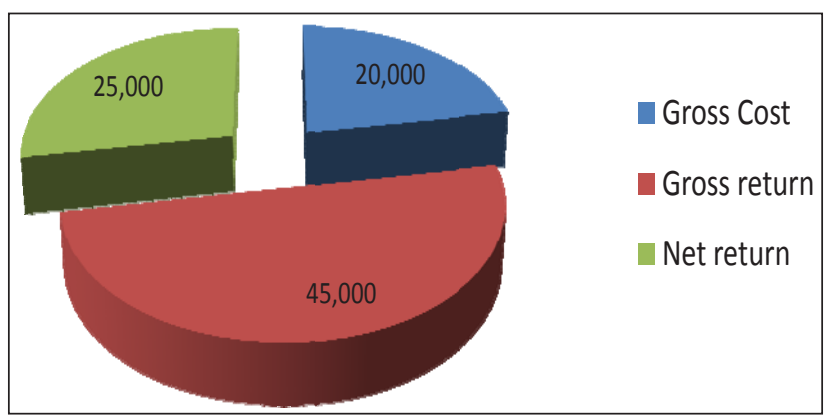

Custom Hiring Centre: Mechanization brings in timeliness and precision to agricultural operations, greater field coverage over a short period, costeffectiveness, efficiency in use of resources and applied inputs, conservation of available soil moisture under stress conditions and provision of adequate drainage of excess rain and floodwaters. 
Custom hiring centres (CHCs) for farm implements were established in NICRA villages which could successfully empower farmers to tide over the shortage of labour and improve efficiency of agricultural operations. A committee of farmers' nominated by the rangbah shnong (Village Headman) manages the custom hiring centre. The rates for hiring the machines/ implements are decided by the Village Climate Risk Management Committee (VCRMC). This committee also uses the revenue generated from hiring charges for repair and maintenance of the implements and remaining amount goes into the revolving fund. There are 28 different types of farm machinery stocked in CHCs, the most popular are power tiller, knapsack sprayer, paddy thrasher, maize sheller and small water pump. A total net balance of ₹ 47,115 has been generated so far facilitating the adoption of climate resilient practices and technologies by farmers because of availability of appropriate machines at reasonable hiring charges.

\section{CONCLUSION}

The present study emphasized impact of climate resilient technologies demonstrated at NICRA village. Significant difference of cropping intensity through crop diversification during kharif, rabi and summer seasons which resulted in income savings and expenditure pattern of the NICRA beneficiaries. Yields of all the crops demonstrated at NICRA farms found measurable difference with increase in yields. This might be due to implementation of climate resilient improved varieties tied with better water and healthy soil management practices. Mechanization of agricultural operations through Custom Hiring Centre, timely availability of inputs and climate resilient technologies, soil test based farming, increased awareness through various training programs and extension activities might be the reason of the significant findings of present study. All the above findings exhibited an encouraging impact of the demonstrated technologies in various spheres of farmer's life of NICRA village.

\section{REFERENCES}

Antle, J.M. and Capalbo, S.M. 2001. Econometric-processes models for integrated assessment of agriculture production systems. American Journal of Agricultural Economics, 83(2): 389-401.
Berbery, H., Doyle, M., and Barros, V.2006. Tendenciasregionales de la precipitación. In: El cambioclimático en la Cuenca del Plata, Barros V, Clarke R, Silva Dias P (eds). CONICET, Buenos Aires.

Das, A., Patel, D.P., Ramkrushna, G.I., Munda, G.C., Ngachan, S.V., Choudhury, B.U., Mohapatra, K..P, Rajkhowa, D.J., Kumar, R., Panwar, A.S. (2012) Improved rice production technology - for resource conservation and climate resilience (Farmers' Guide). Ext Bull No. 78. ICAR Research Complex for NEH region, Umiam, Meghalaya, p 29.

Das, A, Patel, D.P., Munda, G.C., Ramkrushna, G.I., Kumar, M. and Ngachan, S.V. 2014. Improving productivity, water and energy use efficiency in lowland rice (Oryza sativa) through appropriate establishment methods and nutrient management practices in the mid-altitude of north-east India. Experimental Agriculture, 50(3): 353-375.

Econometric-processes models for integrated assessment of agriculture production systems. American Journal of Agricultural Economics, 83(2): 389-401.

Greg, E.E., Anam, B.E., William, M.F. and Duru, E.J.C. 2011. 'Climate change, food security and agricultural productivity in African: Issues and policy directions', International Journal of Humanities and Social Science, 1(21): 205-223.

Jasna, V.K., Burman, R.R., Padaria, R.N., Sharma, J.P., Varghese, E., Chakrabarti, B. and Dixit, S. 2017. Impact of climate resilient technologies in rainfed agroecosystem. Indian Journal of Agricultural Sciences, 87(6): 816-824.

Khan, S.A., Kumar, S., Hussain, M.Z. and Kalra, N. 2009. Climate change, climate variability and Indian agriculture - impacts vulnerability and adaptation strategies http:// www.springer.com/978-3-540- 88245-9 Accessed 09 August, 2017.

KVK Ri Bhoi Annual Report 2011-2017. Submitted by Senior Scientist and Head, KVK, Ri Bhoi.

Malla, G. 2014. Innovative measures for mitigating negative effects of climate change on hill agriculture in Nepal. Journal of Hill Agriculture, 5(2): 87-91.

Mann, R.A. and Meisner, C.A. 2003. Proceedings of the national workshop on rice-wheat systems in Pakistan, 1112th December, 2002. Islamabad, Pakistan. A Rice Wheat Consortium Paper Series 15. pp. 2-3.

Meinke, H., Nelson, R., Kokic, P., Stone, R., Selvaraju, R. and Baethgen, W. 2006. Actionable knowledge: from analysis to synthesis. Climate Research, 33: 101-110.

Parry, M.L. and Carter, T.R. 1989. The impact of climate change on agriculture. In: Coping with Climate Change. Proceedings of the 2nd North American Conference on Preparing for Climate Change, Topping JC (ed). Climate Institute, Washington, DC, pp. 180-184. 
Schrooten, M. and Stephan, S. 2003. Private savings in eastern European EU - accession countries: evidence from a dynamic panel data model. German Institute for Economic Research, Berlin.

Uphoff, N., Kassam, A., Thakur, A., Jagannath, P., Pullabhotla, H., Jiaguo, Z., Zhongzhi, C., Xuyi, L., Xinlu, J., Ndiiri, J.A. and Mati, B.M. 2013. Challenges of increasing water saving and water productivity in the rice sector: introduction to the system of rice intensification (SRI) and this issue. Taiwan Water Conservation, 61(4): 1-13.
Wezel, A., Casagrande, M., Celette, F., Vian, J.F., Ferrer, A. and Peigne, J. 2014. Agroecological practices for sustainable agriculture- a review. Agronomical Sustainable Development, 34: 1-20. 